\title{
Zn finger-based direct detection system for PCR products of Salmonella spp. and the Influenza A virus
}

\author{
Yuko Osawa - Kazunori Ikebukuro · Takenori Kumagai · \\ Hiroaki Motoki - Takafumi Matsuo • \\ Michio Horiuchi · Koji Sode
}

Published online: 10 March 2009

(C) Springer Science+Business Media B.V. 2009

\section{Erratum to: Biotechnol Lett \\ DOI 10.1007/s10529-009-9927-2}

The list of authors in the original publication was incomplete. The correct author list is shown in this erratum.

Y. Osawa · K. Ikebukuro $(\bowtie) \cdot$ T. Kumagai · K. Sode Department of Biotechnology and Life Science, Tokyo University of Agriculture \& Technology, 2-24-16,

Naka-cho, Koganei, Tokyo 184-8588, Japan

e-mail: ikebu@cc.tuat.ac.jp

H. Motoki · T. Matsuo · M. Horiuchi

System Instruments Co., Ltd, 776-2 Komiya-cho,

Hachioji, Tokyo 192-0031, Japan 